\title{
Analysis of the effect exerted by extracellular pH on the maltose regulon in Escherichia coli K-12
}

\author{
Sylvie Alonzo, Martine Heyde, Patrick Laloi and Raymond Portalier
}

Author for correspondence: Patrick Laloi. Tel: +33472431 621. Fax: +33472431971. e-mail: plaloi@biomserv.univ-lyon1.fr

Laboratoire de Microbiologie et Génétique Moléculaire, Centre de Génétique Moléculaire et Cellulaire, UMR CNRS 5534 ,

Université Claude Bernard, 69622 Villeurbanne Cedex, France

\begin{abstract}
The Escherichia coli maltose regulon consists of five operons under the control of the MalT transcriptional activator. lac operon fusions were constructed in vitro with the MalT-dependent promoter and with the malT promoter itself. $\beta$-Galactosidase activity displayed by these fusions during growth at different external $\mathrm{pH}\left(\mathrm{pH}_{\mathrm{o}}\right)$ revealed that growth at a $\mathrm{pH}_{\mathrm{o}}$ higher than 6 stimulates the transcription of malT- and MalT-controlled genes in the absence or presence of maltose. Using a malTp1 malTp10 promoter that is CAMP-CRP (CAMP receptor protein)-independent, it was demonstrated that CRP is essential for malT $\mathrm{pH}_{\text {。 }}$ regulation and that the $\mathrm{pH}_{\mathrm{o}}$-dependent activity of malKp is a direct consequence of malt regulation. The $\mathrm{pH}_{0}$ regulation displayed by a deleted but still functional malT promoter fused to lacz demonstrates that this minimal promoter contains all the regulatory regions for establishing $\mathrm{pH}_{\mathrm{o}}$ regulation. In the absence of Mlc, a repressor of malt expression, the $\mathrm{pH}_{\mathrm{o}}$ regulation of malr was still effective. It is proposed that binding of CAMP-CRP at malTp may be affected by malTp topology induced by $\mathrm{pH}_{\mathrm{o}}$ or that a $\mathrm{pH}_{0}$-dependent effector may act in concert with the CAMP-CRP complex.
\end{abstract}

Keywords: Escherichia coli, transcription, cAMP-CRP, maltose regulon, $\mathrm{pH}$

\section{INTRODUCTION}

To contribute to the understanding of the complex molecular interplay between the different regulatory mechanisms and environmental signals that influence gene expression, we have studied the influence of external $\mathrm{pH}\left(\mathrm{pH}_{\mathrm{o}}\right)$ on the expression of the Escherichia coli $\mathrm{K}-12$ maltose regulon. E. coli has a constitutive homeostatic mechanism which allows cells to maintain their internal $\mathrm{pH}$ between $7 \cdot 4$ and $7 \cdot 8$ over a $\mathrm{pH}_{\mathrm{o}}$ range of 5.0-8.5 (Zilberstein et al., 1984). Therefore, within this $\mathrm{pH}_{0}$ range, regulation of gene expression in response to $\mathrm{pH}_{\mathrm{o}}$ must involve mechanisms capable of sensing and transducing the $\mathrm{pH}_{\mathrm{o}}$ stimulus. In $E$. coli, the level of expression of many genes is influenced by the $\mathrm{pH}_{\mathrm{o}}$ (for a review, see Olson, 1993). We have described in vivo gene fusions whose expression is increased during growth at high $\mathrm{pH}_{0}$ compared to low $\mathrm{pH}_{\mathrm{o}}$ (Heyde et al., 1991). The mal $B$ region, which belongs to the maltose regulon, was identified among the different $\mathrm{pH}_{0}$-modulated loci.

Abbreviations: CRP, cAMP receptor protein; $M M$, minimal medium; $\mathrm{pH}_{0}$ ， external $\mathrm{pH}$.
The maltose regulon of $E$. coli consists of numerous genes whose products are involved in the transport and catabolism of maltose and maltodextrins (Schwartz, 1987; Boos et al., 1996). These genes belong to five transcriptional units under the control of a transcriptional activator, the MalT protein (Richet \& Raibaud, 1989). Three MalT-dependent operons (malPQ, mals and malZ) are independent of the cAMP receptor protein (CRP), whereas the other two, malKlamB-malM and malEFG require the cAMP-CRP complex in addition to MalT (Chapon, 1982). MalT appears monomeric in solution and, in the absence of inducer, is in an inactive form $\left(\mathrm{MalT}_{\mathrm{i}}\right)$. The binding of ATP $\left(K_{\mathrm{D}}\right.$ $0.4 \mu \mathrm{M}$; Richet \& Raibaud, 1989) and maltotriose $\left(K_{\mathrm{D}}\right.$ about $20 \mu \mathrm{M}$; Raibaud \& Richet, 1987) to MalT $_{i}$ stabilizes active MalT $\left(\mathrm{MalT}_{\mathrm{a}}\right.$ ) for transcriptional activation. malT expression is not autoregulated, but is subject to catabolite repression and requires the presence of the cAMP-CRP complex (Chapon, 1982; Chapon \& Kolb, 1983). It is also controlled by a repressor called Mlc, a putative new global regulator for sugar metabolizing systems. In the absence of Mlc, malT expression is increased by a factor of 2-3 when E. coli is grown in glycerol (Decker et al., 1998). Mlc binds to malT DNA 
Table 1. Bacterial strains and plasmids

Genetic nomenclature is from Bachmann (1990). Transductants were selected for the first phenotype indicated and analysed for the second one. $\mathrm{Tet}^{\mathrm{R}}, \mathrm{Kan}^{\mathrm{R}}, \mathrm{Cam}^{\mathrm{R}}, \mathrm{Amp}^{\mathrm{R}}$ indicate resistance to tetracycline, kanamycin, chloramphenicol or ampicillin, respectively. $\mathrm{Mrl}^{+}$indicates growth with mannitol as carbon source.

\begin{tabular}{|c|c|c|}
\hline Strain/plasmid & Relevant genotype & Source or reference \\
\hline \multicolumn{3}{|c|}{ Strains cited in the figures or in the text } \\
\hline GPH1767 & MC4100(pGPH1767) & This work \\
\hline GPH1768 & MC4100(pGPH1768) & This work \\
\hline GPH8561 & pop3325(pGPH1768) & This work \\
\hline GPH8805 & MC4100 (ompA::lacZ)hyb & $\mathrm{Kan}^{\mathrm{R}}$ with P1 on JC4948 \\
\hline GPH8879 & MC4100(pGPH8879) & This work \\
\hline GPH8881 & MC4100(pGPH8881) & This work \\
\hline GPH8888 & GPH1768 malQ:: Tn10 & Tet $^{\mathrm{R}}$ with $\mathrm{P} 1$ on pop4064 \\
\hline GPH8892 & GPH8549(pGPH8881) & This work \\
\hline GPH9274 & MC4100(pGPH9261) & This work \\
\hline \multicolumn{3}{|c|}{$\begin{array}{l}\text { Strains used as starting material or as an intermediate during the construction of the above } \\
\text { strains }\end{array}$} \\
\hline BG525 & $\Delta c y a 06 \Delta c r p 45$ thi & Institut Pasteur, Paris \\
\hline BS524 & $\Delta c y a 06$ & $\begin{array}{l}\text { J. Beckwith, Harvard Medical } \\
\text { School }\end{array}$ \\
\hline BS680 & thi $\Delta$ crp 45 aroB & Institut Pasteur, Paris \\
\hline CA8404 & $c r p^{*} r p s L$ & $\begin{array}{l}\text { J. Beckwith, Harvard Medical } \\
\text { School }\end{array}$ \\
\hline CGSC6419 & $\mathrm{F}^{-} \Delta\left(\right.$ lacZY 286 zie296:: Tn10 xyl-7 mtl-1 argH1 $\lambda^{-}$ & B. Bachmann, Yale University \\
\hline GPH6794 & BS680 zhe: : Tn10 aroB & Tet $^{\mathrm{R}}$ with P1 on $\mathrm{K} 311 / 1$ \\
\hline GPH6977 & BS524 zie296::Tn10 & Tet $^{\mathrm{R}}$ with P1 on CGSC6419 \\
\hline $\mathrm{K} 311 / 1$ & $\mathrm{~K} 311$ aro $B$ zhe : $: \operatorname{Tn} 10$ & V. Braun, University of Tübingen \\
\hline KD612 & MC4100 $\Phi\left(m a l T^{\prime}-l a c Z\right) 1110(\lambda$ placMu50) mlc::Tn10Kan & Decker et al. (1998) \\
\hline MC4100 & $\begin{array}{l}\mathrm{F}^{-} \text {araD139 } \Delta(\arg F-l a c) 205 \lambda^{-} \text {flbD5301 fruA25 relA1 rpsL150 rbsR22 } \\
\text { deoC1 }\end{array}$ & $\begin{array}{l}\text { M. Casadaban, University of } \\
\text { Chicago }\end{array}$ \\
\hline pop3325 & MC4100 $\operatorname{malT}^{\mathrm{e}} 1$ & Institut Pasteur, Paris \\
\hline pop4064 & MC4100 malQ::Tn10 & E. Richet, Institut Pasteur, Paris \\
\hline pop4125 & MC4100 malTp1 malTp10/F $\mathrm{F}^{+}$ & E. Richet, Institut Pasteur, Paris \\
\hline pop4127 & MC4100 malTp1 malTp10 zhd:: Tn10 $\Delta c r p T 8 / \mathrm{F}^{+}$ & E. Richet, Institut Pasteur, Paris \\
\hline TE2680 & 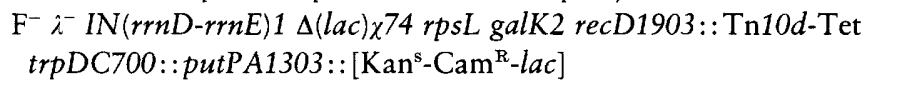 & Elliott $(1992)$ \\
\hline \multicolumn{3}{|c|}{ S } \\
\hline pBR328 & $\mathrm{Amp}^{\mathrm{R}} \mathrm{Tet}^{\mathrm{R}} \mathrm{Cam}^{\mathrm{R}}$ & \\
\hline pJEL249 & $\begin{array}{l}\text { Amp }^{\mathrm{R}}\left(30 \mu \mathrm{g} \mathrm{ml}^{-1}\right) . \text { Temperature-sensitive copy number. lac } Z Y A \\
\text { gene fusion vector }\end{array}$ & Valentin-Hansen et al. (1986) \\
\hline
\end{tabular}


Table 1. (cont.)

\begin{tabular}{|c|c|c|}
\hline Strain/plasmid & Relevant genotype & Source or reference \\
\hline pJEL250 & $\begin{array}{l}A_{m p}^{R}\left(30 \mu \mathrm{g} \mathrm{m}^{-1}\right) . \text { Temperature-sensitive copy number. lac } Z Y A \\
\text { operon fusion vector }\end{array}$ & Valentin-Hansen et al. (1986) \\
\hline pGPH1767 & $\Phi\left(\right.$ malE $\left.-l a c Z^{+}\right) 1$ in pJEL250 & This work \\
\hline pGPH1768 & $\Phi\left(\right.$ malK $^{\prime}-$ lac $\left.^{+}\right) 1$ in $\mathrm{pJEL} 250$ & This work \\
\hline pGPH8579 & See Methods & This work \\
\hline pGPH8881 & $\Phi\left(\right.$ mal T$^{\prime}-$ lac $\left.^{+}\right) 1$ in pJEL 250 & This work \\
\hline pGPH9260 & $\Phi\left(\right.$ malTp1 malTp10 $\left.0^{\prime}-l a c Z^{+}\right) 1$ in pJEL250 & This work \\
\hline pGPH9261 & $\Phi\left(\Delta m a l T^{\prime}-\right.$ lac $\left.^{+}\right) 2$ in $\mathrm{pJEL} 250$ & This work \\
\hline pGPH9463 & $\Phi\left(\right.$ malP'-lacZ $\left.Z^{+}\right) 1$ in $\mathrm{pJEL} 250$ & This work \\
\hline
\end{tabular}

at a position 1 to $23 \mathrm{bp}$ from the start of the malT transcript. The expression of the maltose regulon is induced when maltose or maltodextrins are present in the growth medium (exogenous induction). Low uninduced expression is controlled by the internal synthesis of inducers (endogenous induction) and is strongly repressed at high osmolarity. The induced level of maltose regulon expression is not affected by osmolarity (Bukau et al., 1986). In addition to its role in transport, MalK influences maltose gene expression, probably by competing with the endogenous inducer for $\mathrm{MalT}_{\mathrm{i}}$. Decker et al. (1993) postulated that in the absence of MalK, MalT would not require an inducer to be active.

Here, we describe the effects of $\mathrm{pH}_{0}$ on the activity of the malEp, malKp, malP $p$, mal $S p$ and malTp promoters and demonstrate that $\mathrm{pH}_{\mathrm{o}}$ modulation of MalT-dependent genes is a direct consequence of malT $\mathrm{pH}_{\mathrm{o}}$ modulation. We provide evidence that the cAMP-CRP complex is involved in $\mathrm{pH}_{\mathrm{o}}$-dependent malTp activity.

\section{METHODS}

Bacterial strains, plasmids and media. Bacterial strains and plasmids used in this study are listed in Table 1 . Standard media were used in this study, including LB broth (Miller, 1992), MacConkey (MC) (Difco) and M63 minimal medium (MM; Miller, 1992) supplemented with $3 \mu \mathrm{M}$ thiamine hydrochloride, the appropriate amino acids and various sugars as carbon source. Buffered MM contained $50 \mathrm{mM}$ MES, $50 \mathrm{mM}$ TAPS, $40 \mathrm{mM} \mathrm{KCl}, 21 \mathrm{mM} \mathrm{NH}_{4} \mathrm{Cl}, 100 \mu \mathrm{M} \mathrm{CaCl}_{2}$, $1 \mathrm{mM} \mathrm{MgCl}, 0.7 \mu \mathrm{M} \mathrm{FeCl}_{3}, 25 \mu \mathrm{M} \mathrm{Na}_{2} \mathrm{SO}_{4}, 1 \mathrm{mM} \mathrm{KH} \mathrm{HO}_{4}$ and $50 \mathrm{mM} \mathrm{NaCl}$ (Heyde et al., 1991). These media were adjusted with $1 \mathrm{M} \mathrm{NaOH}$ or $1 \mathrm{M} \mathrm{HCl}$ to $\mathrm{pH} 4 \cdot 75,5,5 \cdot 25,5 \cdot 5$, $5.75,6.5,7,7.5$ and 8 . An osmolarity of about $340 \mathrm{mOsm}$ for MM was determined by measuring the freezing point with an osmometer (Fiske type OS/220). MM was supplemented with $3 \mu \mathrm{M}$ thiamine hydrochloride and $44 \mathrm{mM}$ glycerol as carbon source. Maltose $(58 \mathrm{mM})$ was added to this basal $\mathrm{MM}$ to induce the maltose regulon. When required, antibiotics were added at the following concentrations: $100 \mu \mathrm{g}$ ampicillin $\mathrm{ml}^{-1} ; 50 \mu \mathrm{g}$ kanamycin $\mathrm{ml}^{-1} ; 15 \mu \mathrm{g}$ tetracycline $\mathrm{ml}^{-1} ; 30 \mu \mathrm{g}$ ampicillin $\mathrm{ml}^{-1}$ for $\mathrm{PJEL}$ derivatives.

Growth conditions. Overnight subcultures, grown in LB at $30^{\circ} \mathrm{C}$, were used for inoculating $\mathrm{MM}$ adjusted to different $\mathrm{pH}_{\mathrm{o}}$ values and supplemented with glycerol (basal medium) or glycerol and maltose (inducer medium). These cultures were incubated at $30^{\circ} \mathrm{C}$ until stationary phase was reached. At this point, the different buffered cultures were diluted with the same fresh medium to an $\mathrm{OD}_{600}$ of 0.02 (path length $1 \mathrm{~cm}$, Jouan spectrophotometer). These new cultures were incubated at $30^{\circ} \mathrm{C}$ up to an $\mathrm{OD}_{600}$ between $0 \cdot 2$ and $0 \cdot 3$. Up to this cell density, the $\mathrm{pH}$ of the growth medium remains constant. Five millilitre cultures were grown in sterile culture tubes $(20 \mathrm{~mm}$ diam.) and aerated in a gyratory water bath at 200 r.p.m.

Enzyme assays. $\beta$-Galactosidase activities associated with operon or gene fusions were measured on toluenized cells as described previously (Heyde \& Portalier, 1987). One unit (U) of $\beta$-galactosidase activity was defined as the amount of enzyme that hydrolysed $1 \mathrm{nmol}$ substrate $\mathrm{min}^{-1}$. Independent experiments were performed and results were averaged to obtain the indicated values. Error bars display the SD. The absence of error bars indicates that the SD fell below the resolution limit of the graphing program.

In vitro plasmid construction. Plasmid DNA extraction, restriction endonuclease analysis, cloning, transformation and Southern blotting procedures were as described by Maniatis $e t$ al. (1982). All constructions in pJEL plasmid vectors were controlled by plasmid DNA sequencing, carried out using the dideoxy chain-termination method and the Oncor Fidelity kit (Appligene), according to the manufacturer's instructions. pGPH1767 and pGPH1768 are pJEL250 derivatives containing, respectively, malEp and malKp promoters of the malB region. Cloning of the $481 \mathrm{bp}$ EcoRI fragment from pOM18 (Raibaud et al., 1989) into the EcoRI site and in both orientations resulted in the $\left(\right.$ malE $\left.E^{\prime}-l a c Z^{+}\right) 1$ and $\left(\right.$ malK'-lac $\left.Z^{+}\right) 1$ operon fusions. pGPH9463 and pGPH8881 are pJEL250 derivatives containing, respectively, malP $p$ and malTp promoters of the malA region. Cloning of the $811 \mathrm{bp}$ EcoRI fragment from pOM12 (Chapon \& Kolb, 1983) into the EcoRI site and in both orientations resulted in the $\left(\right.$ malP $\left.P^{\prime}-l a c Z^{+}\right) 1$ and $\left(\right.$ malT $T^{\prime}-$ lac $\left.Z^{+}\right) 1$ operon fusions. Insertion of the same $811 \mathrm{bp}$ fragment in-frame with lac $Z$ into the EcoRI site of pJEL249 gave pGPH8879 which harbours an active ( $m a l T^{\prime}-$ lacZ) 1 hyb gene fusion. pGPH9261 is a pJEL250 derivative containing a minimal malTp promoter deleted for the upstream region. Cloning of a blunt-ended $560 \mathrm{bp} \mathrm{SalI-ClaI} \mathrm{fragment} \mathrm{from}$ pOM2 (Raibaud et al., 1985) into the blunt-ended EcoRI site of pJEL250 gave the $\left(\Delta\right.$ malT $\left.T^{\prime}-l a c Z^{+}\right) 2$ operon fusion. pGPH8579 contains the whole malB region, except the $3^{\prime}$ end 
of the malM gene which was inserted as a BamHI-PvuII fragment into plasmid pBR328. This $12013 \mathrm{bp}$ recombinant plasmid carries the ampicillin resistance gene. pGPH8579K is a derivative of pGPH8579 with a kanamycin resistance cassette (Genblock, Pharmacia) inserted into the EcoRI site of the malk gene.

In vivo genetic methods. Generalized transduction with P1vir was performed according to Miller (1992). The (malTp1 malTp10-lac $\left.Z^{+}\right) 1$ operon fusion was constructed by allelic exchange between the chromosome of pop4127 (malTp1 malTp10 $\Delta c r p \Delta l a c)$ and the plasmid-borne $\left(m a l T^{\prime}\right.$-lac $\left.Z^{+}\right) 1$ operon fusion. pop4127 was infected by P1 lysate and propagated on the GPH8881 strain $(\Delta l a c)$ which harboured the plasmid-borne $\left(\right.$ malT-lac $\left.Z^{+}\right) 1$ operon fusion. $\mathrm{Lac}^{+} \mathrm{Amp}^{\mathrm{R}}$ colonies were selected. They were unable to metabolize maltose. These colonies result from the transfer of the plasmid into pop4127 and subsequent allelic exchange between chromosomal malTp1 malTp10 and wild-type plasmid-borne malT promoters. Indeed, plasmid-borne lacZYA could be expressed in the $\Delta c r p$ background (pop4127) only if the malTp1 malTp10 promoter was substituted to the malT promoter on the plasmid. Moreover, the chromosomal malT gene cannot be expressed in the $\Delta c r p$ background. The strain became $\mathrm{Mal}^{-}$if the wild-type malT promoter was substituted to the malTp1 malTp10 promoter. A plasmid harbouring the (malTp1 malTp10'-lac $\left.Z^{+}\right) 1$ operon fusion was named pGPH9260. The presence of the malTp10 mutation was checked by the presence of a new EcoRI site introduced by the mutation. Then, competent cells of strain MC4100 were transformed with pGPH9260 resulting in strain GPH9275. The inactivation of the chromosomal malK gene was done with the help of pGPH8579K. This plasmid, which carries malK'-Kan ${ }^{\mathrm{R}}{ }^{\prime}$ 'malK, was linearized with EagI restriction endonuclease and then used to transform electro-competent cells of TE2680. $\mathrm{Kan}^{\mathrm{R}}$ white clones were selected on MC maltose kanamycin medium. In these clones, the chromosomal malK gene was interrupted by the kanamycin cassette. This construct was then transferred into the MC4100 strain by P1 transduction. The correct insertion of the cassette was confirmed by Southern blotting.

\section{RESULTS}

\section{Expression of the maltose regulon is $\mathrm{pH}_{0}$-modulated}

Previous studies have shown that malB expression is $\mathrm{pH}_{\mathrm{o}}$-regulated (Heyde \& Portalier, 1987; Heyde et al., 1991). To determine if the $\mathrm{pH}_{\mathrm{o}}$ effect operates at the transcriptional level on malA and malB operons, lac operon fusions with malPp, malKp and malEp were constructed in vitro using pJEL250 (Valentin-Hansen $e t$ al., 1986; see Methods). A chromosomal mals-lacZ operon fusion (Freundlieb \& Boos, 1986) was also analysed. The use of the temperature-sensitive pJEL250 replicon allowed us to maintain malp-lacZ fusion copy numbers similar to chromosomal maltose promoters, thus minimizing a possible titration of regulatory factors by excess copies of reporter constructs. Moreover, the use of plasmid operon fusions, which maintained a functional maltose regulon in the cell, prevented the alteration of more subtle regulatory circuits.

Fig. 1 shows that growth in $M M$ at neutral or higher $\mathrm{pH}_{\mathrm{o}}$ stimulated transcription initiated at malKp (Fig. 1a, b), malEp (c, d), malPp (f) and malSp (g) in the absence or presence of maltose, but did not stimulate the expression of the ompA gene (e) which was previously reported to be $\mathrm{pH}_{0}$-independent (Heyde et al., 1991). The $\mathrm{pH}_{\mathrm{o}}$ regulation of maltose genes also led to variations in the concentrations of LamB (Heyde \& Portalier, 1987) and MalQ (data not shown). Depending on promoters and growth conditions, $R$ values, which correspond to the ratio between $\beta$-galactosidase activity during growth at $\mathrm{pH}_{0} 6.5$ and 4.75 , varied from 3 to 26 (Fig. 1). Uninduced (basal) malKp activity displayed an $R$ value of $8 \pm 3$, higher than the $R$ value for induced malKp activity $(3.5 \pm 0.5)$ (compare Fig. $1 \mathrm{a}$ with $1 \mathrm{~b}$ ). Finally, as both basal and induced activities of maltose promoters depend on $\mathrm{pH}_{o}$, variation in the level of endogenous inducer concentration as a function of $\mathrm{pH}_{0}$ could not alone explain the $\mathrm{pH}_{\mathrm{o}}$ regulation of maltose genes.

\section{Effect of $\mathrm{pH}_{\mathrm{o}}$ on malT regulatory gene expression}

Since the expression of all maltose promoters requires activation by the MalT regulatory protein, we first tested if the $\mathrm{pH}_{0}$ regulation of the maltose regulon was the mere consequence of $\mathrm{pH}_{\mathrm{o}}$-dependent malTp activity. lac operon or gene fusions with malTp were constructed in vitro using pJEL250 or pJEL249, respectively (see Methods). Fig. 2(a) and (b) show that the expression of $\left(m a l T^{\prime}-l a c Z^{+}\right) 1$ operon and $\left(m a l T^{\prime}-l a c Z\right) 1$ hyb gene fusions was stimulated during growth in $M M$ at neutral or higher $\mathrm{pH}_{0}$, with $R$ values ranging from $3 \pm 0.5$ to $6 \pm 2 \cdot 4$. $R$ values obtained with operon and gene fusions were not significantly different. These results indicate that during growth in MM, malT expression is predominantly $\mathrm{pH}_{\mathrm{o}}$-regulated at the transcriptional level. We previously showed that during growth in LB medium, malT expression remains constant whatever the $\mathrm{pH}_{\mathrm{o}}$ (Heyde et al., 1991). We re-examined malT expression during growth in buffered LB medium and found that it was $\mathrm{pH}_{\mathrm{o}}$-regulated with an $R$ value of 2 . Therefore, malT $\mathrm{pH}_{0}$ regulation was not specific to growth in $\mathrm{MM}$. For $\mathrm{pH}_{\mathrm{o}}$ values lower than 5.75, we observed a strong correlation between the increase in malT $p$ activity and malKp, malEp and malP $p$ activities (compare Fig. 2a to Fig. 1). For $\mathrm{pH}_{\mathrm{o}}$ values higher than 5.75 , the increase of malTp activity contrasted with decreased or steady activity of maltose promoters. The correlation between malTp and malKp activities for $\mathrm{pH}_{\mathrm{o}}$ values lower than 5.75 strongly suggests that the $\mathrm{pH}_{0}$-dependent malTp activity is responsible for $\mathrm{pH}_{\mathrm{o}}$ modulation of maltose gene expression.

\section{Characterization of $\mathrm{malT} \mathrm{pH}_{\mathrm{o}}$ modulation}

malT gene transcription requires the binding of the cAMP-CRP complex on malTp (Chapon \& Kolb, 1983) and is repressed by the binding of Mlc (Decker $e t$ al., 1998). The effect of DNA deletion upstream of malT was analysed with the construction of a $\left(\Delta\right.$ malT $^{\prime}-$ lac $\left.^{+}\right) 2$ operon fusion in which DNA upstream of position -120 relative to the start of transcription was lacking (Fig. 3a). The effect of an mlc::Tn10Kan insertion on malT transcription was analysed with the $\left\langle\right.$ mal $T^{\prime}$ lac $\left.Z^{+}\right) 1$ operon fusion (Fig. 3a). Data from these 

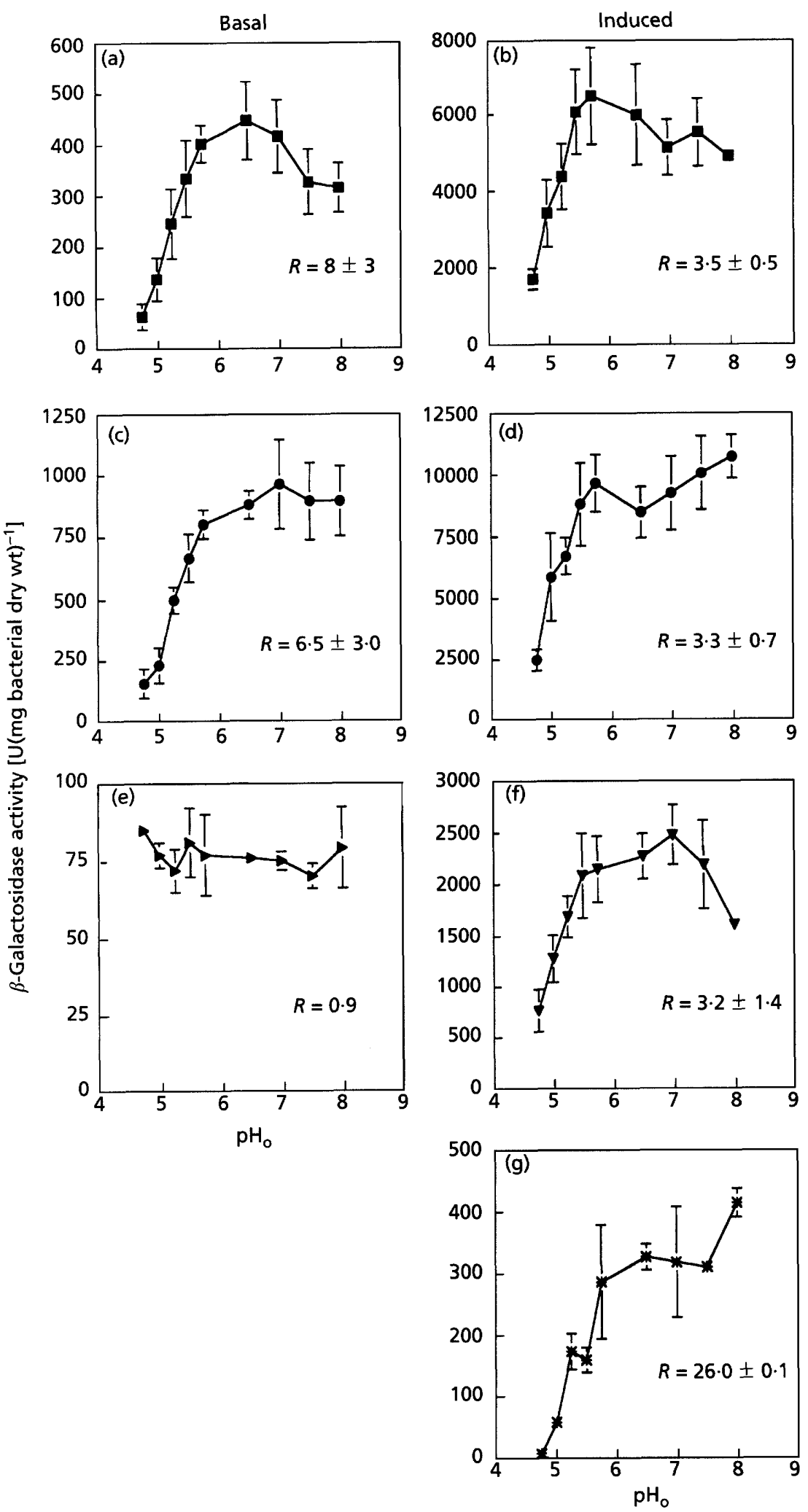

Fig. 1. Influence of $\mathrm{pH}_{\mathrm{o}}$ on the transcription of maltose genes. $\beta$-Galactosidase activity was assayed during growth at $30^{\circ} \mathrm{C}$ in $\mathrm{MM}$ adjusted to different $\mathrm{pH}$ values and supplemented with glycerol ( $a, c$ and $e$ ) or glycerol and maltose (b, $d, f$ and $g$ ), and ampicillin for plasmid-containing strains. Data are the mean values $( \pm S D)$ from at least three independent experiments. $R$ values correspond to the ratios between $\beta$ galactosidase activities at $\mathrm{pH}_{\mathrm{o}} 6.5$ and 4.75 . mals and malP expression was not assayed in the absence of maltose because basal expression was not detected. $(a, b)$ (malK'$\left.\operatorname{lac} Z^{+}\right) 1$ operon fusion on PJEL250 (GPH1768). (c, d) (malE'-lacZ+)1 operon fusion on pJEL250 (GPH1767). (e) (ompA::/acZ)hyb chromosomal gene fusion (GPH8805). (f) (malP'-lacZ+)1 operon fusion on pJEL250 (GPH9463). (g) (mals'-lac $\left.Z^{+}\right) 1$ chromosomal operon fusion (SF1707). experiments showed that malT transcription is increased in the absence of Mlc compared to the wild-type strain but is still $\mathrm{pH}_{\mathrm{o}}$-regulated (Fig. 3a). To elucidate the role of cAMP-CRP in malT $\mathrm{pH}_{\mathrm{o}}$ modulation, both malTp1 and malTp10 mutations were introduced, by in vivo recombination, into the plasmid-borne (mal $T^{\prime}$ lac $\left.Z^{+}\right) 1$ operon fusion to produce the (malTp1 malTp10-lac $\left.Z^{+}\right) 1$ operon fusion (see Methods). The malTp1 mutation makes the -10 sequence closer to the consensus TATAAT box, allowing constitutive malT 

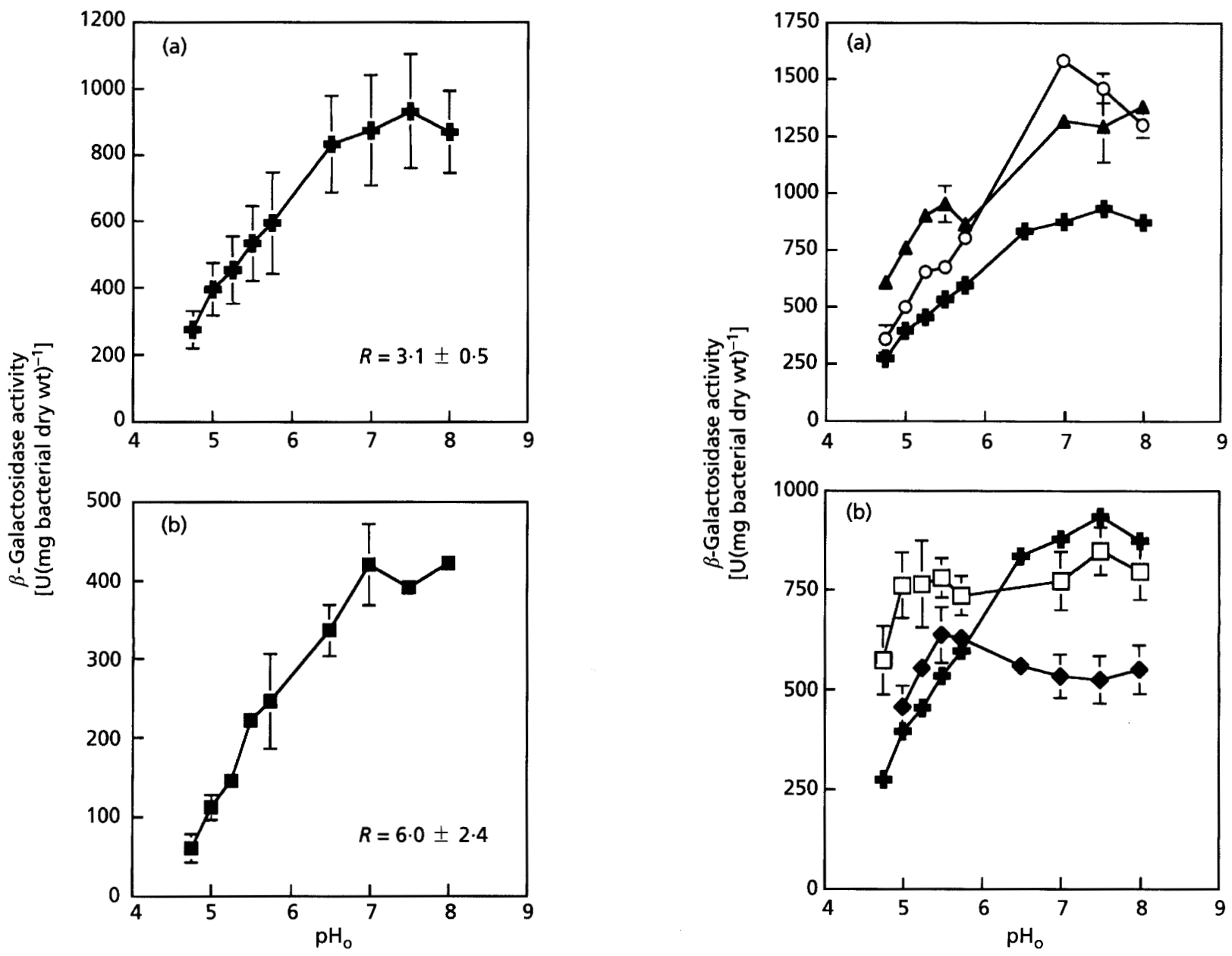

Fig. 2. Influence of $\mathrm{pH}_{\mathrm{o}}$ on malT gene expression. $\beta$ Galactosidase activity was assayed during growth at $30^{\circ} \mathrm{C}$ in MM adjusted to different $\mathrm{pH}$ values and supplemented with glycerol and ampicillin. Data are the mean values $( \pm S D)$ from at least three independent experiments. $R$ values were calculated as indicated in the legend to Fig. 1. (a) $\left(\mathrm{mal} \mathrm{T}^{\prime}-\mathrm{lacZ} \mathrm{Z}^{+}\right) 1$ operon fusion on pJEL250 (GPH8881). (b) (ma/T'-'lacZ) 1hyb gene fusion on PJEL249 (GPH8879).

transcription in the absence of the cAMP-CRP complex (Chapon, 1982). The malTp10 mutation alters the CRP binding site in malTp and prevents the fixation of the cAMP-CRP complex (Raibaud et al., 1991). Data from Fig. 3(b) show that growth in basal $\mathrm{MM}$ at low $\mathrm{pH}_{0}$ did not repress transcription initiated at $\operatorname{malTp} 1 \operatorname{malTp10}$, leading to high $\mathrm{pH}_{\mathrm{o}}$-independent expression of malT. These results imply that (i) the DNA upstream of -120 and Mlc do not contribute to the repression of malT expression during growth in basal $\mathrm{MM}$ at low $\mathrm{pH}_{0}$ and (ii) the cAMP-CRP complex is required for the $\mathrm{pH}_{\mathrm{o}}$ modulation of malT transcription. To test the role of cAMP in malT gene $\mathrm{pH}_{\mathrm{o}}$ modulation, malT transcription was analysed in a $\Delta c y a c r p^{*}$ genetic background. The $c r p^{*}$ mutation affects the coding sequence of $c r p$ and makes the CRP* protein able to activate cAMPCRP-dependent promoters even in the absence of cAMP (Harman et al., 1986). Fig. 3(b) shows that in the $\Delta c y a$

Fig. 3. Genetic analysis of $m a / T \mathrm{pH}_{\circ}$ regulation. $\beta$-Galactosidase activity was assayed during growth at $30^{\circ} \mathrm{C}$ in $\mathrm{MM}$ adjusted to different $\mathrm{pH}$ values and supplemented with glycerol and ampicillin. Data are the mean values $( \pm S D)$ from at least three independent experiments. $R$ values were calculated as indicated in the legend to Fig. 1. Data for the wild-type strain are those presented in Fig. 2(a). (a) $\left(\Delta\right.$ mal $\left.T^{\prime}-\mathrm{lac} Z^{+}\right) 2$ operon fusion on pJEL250 in wild-type background (GPH9274, O). ( $m a l T^{\prime}$-lacZ $\left.Z^{+}\right) 1$ operon fusion on pJEL250 in the mic::Tn10Kan (GPH9949, $\mathbf{A}$ ) or wild-type (GPH8881, +) genetic background. (b) (malTp1

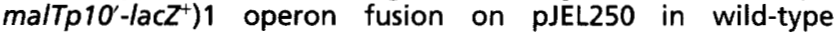
background (GPH9275, $\square$ ). (malT'-lacZ+ $) 1$ operon fusions on pJEL250 in a $\Delta$ cya $\mathrm{crp}^{*}(\mathrm{GPH} 8892, \bullet)$ or wild-type (GPH8881, +) genetic background. The expression of malT in a $\Delta c y a c r p *$ derivative could not be reported at $\mathrm{pH}_{0} 4.75$ because this derivative grew very poorly at this $\mathrm{pH}_{\mathrm{o}}$.

crp* derivative, mal $T$ transcription is less affected by $\mathrm{pH}_{\mathrm{o}}$. This result indicates that $\mathrm{pH}_{\mathrm{o}}$ regulation of malT may be in part related to either $\mathrm{pH}_{\mathrm{o}}$ modulation of the cAMP pool or conformational changes in CRP induced by cAMP binding.

\section{$\mathrm{pH}_{\circ}$ modulation of malK transcription is a consequence of the $\mathrm{pH}_{\mathrm{o}}$ regulation of malT}

As the $\mathrm{pH}_{0}$ modulation of the plasmid-borne (malTp1 malTp $10^{\prime}-$ lac $\left.Z^{+}\right) 1$ operon fusion was abolished (Fig. $3 \mathrm{~b}$ ), the $\mathrm{pH}_{\mathrm{o}}$ regulation of the plasmid-borne (malK'- 


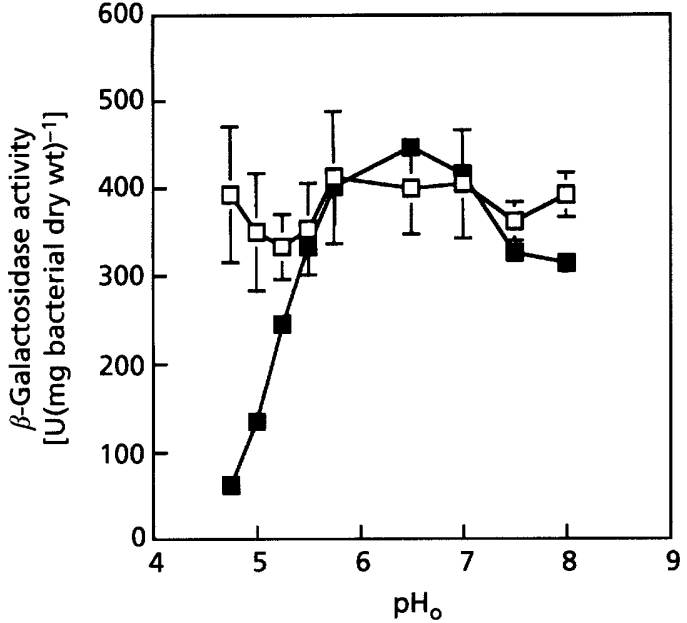

Fig. 4. Influence of the malTp1 malTp10 mutations on malK $\mathrm{pH}_{0}$ regulation. $\beta$-Galactosidase activity was assayed during growth at $30^{\circ} \mathrm{C}$ in $\mathrm{MM}$ adjusted to different $\mathrm{pH}$ values and supplemented with glycerol and ampicillin. Data are the mean values $( \pm S D)$ from at least two independent experiments. Data for the wild-type strain are those presented in Fig. 1(a). (malK'$\left.\mid a C Z^{+}\right) 1$ operon fusion on pJEL250 in a malTp1 malTp10 (GPH8818, $\square$ ) or wild-type (GPH1768, $\mathbf{n}$ ) genetic background.

lac $\left.Z^{+}\right) 1$ operon fusion in the presence of chromosomal malTp1 malTp10 mutations was measured. Data in Fig. 4 show that transcription initiated at malKp was no longer $\mathrm{pH}_{0}$-regulated in the malTp1 malTp10 genetic background. At low $\mathrm{pH}_{0}$, transcription was stimulated and reached the transcription level observed in the wildtype strain during growth at high $\mathrm{pH}_{\mathrm{o}}$ (specific activity of 400). This result clearly demonstrates that the $\mathrm{pH}_{\mathrm{o}}$ dependent activity of malKp is a direct consequence of malT $\mathrm{pH}_{\mathrm{o}}$ regulation. Thus, $\mathrm{pH}_{\mathrm{o}}$ control of $\mathrm{MalT}_{\mathrm{i}}$ synthesis produces subsequent higher amounts of MalT $_{\mathrm{a}}$ at high than at low $\mathrm{pH}_{0}$.

\section{MalT $/ \mathrm{MalT}_{\mathrm{a}}$ equilibrium and $\mathrm{pH}_{\mathrm{o}}$-dependent expression of malK}

The expression of the $\left(\right.$ mal $\left.K^{\prime}-l a c Z^{+}\right) 1$ operon fusion was measured in the presence of the malT $^{\mathrm{c}}$, malK or malQ null mutation. These mutations were previously shown to shift MalT $\mathrm{T}_{\mathrm{i}} / \mathrm{MalT}_{\mathrm{a}}$ equilibrium towards $\mathrm{MalT}_{\mathrm{a}}$. The mal $T^{\mathrm{C}}$ mutation affects the malT coding sequence. It results in the synthesis of a MalT ${ }_{i}{ }_{\text {p }}$ protein with an increased affinity for the inducer and some activity in the absence of maltotriose (Dardonville \& Raibaud, 1990). In such a background (Fig. 5a), the expected (malK'lac $\left.Z^{+}\right) 1$ basal overexpression was observed (specific activity of 2000) and malKp activity was constant whatever the $\mathrm{pH}_{\mathrm{o}}$. The induced expression of malK, controlled by $\mathrm{MalT}^{\mathrm{c}}$, was identical to uninduced expression (Fig. $5 \mathrm{a}$ and $\mathrm{b}$ ), but was lower than the maximal induced expression (specific activity of 6000) observed in the parental strain (Fig. 5b).

The MalQ protein has been shown to remove the endogenous inducer derived from glycogen (Bukau et al., 1986). In the absence of MalQ, the higher amount of endogenous inducer available leads to an increase in the amount of MalT $_{\mathrm{a}}$. Using a previously described malQ null allele, we have shown that, in the absence of MalQ (Fig. 5c), expression of the $\left(\right.$ malK $\left.^{\prime}-\mathrm{lac}^{+}\right) 1$ operon fusions was unusually high and appeared to be less affected by $\mathrm{pH}_{0}(R=2 \pm 0 \cdot 2$ versus $8 \pm 3$ for the parental strain).

In the absence of MalK, the basal expression of the maltose regulon is strongly increased. A putative function of MalK would be to compete with the endogenous inducer for binding to $\mathrm{MalT}_{\mathrm{i}}$ (Decker et al., 1993), leading to lower amounts of $\mathrm{MalT}_{\mathrm{i}}$ available for conversion into $\mathrm{MalT}_{\mathrm{a}}$. In the absence of MalK (Fig. 5d), the expected $\left(\right.$ malK $\left.K^{\prime}-l a c Z^{+}\right) 1$ overexpression was observed, but this expression was still $\mathrm{pH}_{\mathrm{o}}$-dependent $(R$ $=8 \cdot 4 \pm 2.5$ versus $8 \pm 3$ for the parental strain).

Induced conditions and $\mathrm{malT}^{\mathrm{c}}$, malQ or malK mutations have all been shown to shift the $\mathrm{MalT}_{\mathrm{i}} / \mathrm{MalT}_{\mathrm{a}}$ equilibrium towards $\mathrm{MalT}_{\mathrm{a}}$. In the presence of $\mathrm{MalT}^{\mathrm{c}}$ (malT $T^{\mathrm{c}}$ mutation) or without MalQ (malQ mutation), malK expression more or less depends on $\mathrm{pH}_{\mathrm{o}}$. However, without MalK (malK mutation) or in the presence of exogenous inducer (Fig. 1b), malK expression depends on $\mathrm{pH}_{\mathrm{o}}$ as in the parental strain in uninduced conditions. This discrepancy between data obtained with conditions known to shift $\mathrm{MalT}_{\mathrm{i}} / \mathrm{MalT}_{\mathrm{a}}$ equilibrium towards $\mathrm{MalT}_{\mathrm{a}}$ indicates that the increase in $\mathrm{MalT}_{\mathrm{i}}$ conversion would not be the only effect of some of these mutations or induced conditions.

\section{DISCUSSION}

Our results show that during growth in MM, malTp activity is $\mathrm{pH}_{\mathrm{o}}$-dependent, which led to a malT transcription level three times higher at medium $\mathrm{pH}_{\mathrm{o}}$ than at low $\mathrm{pH}_{0}$. This regulation depends on the binding of cAMP-CRP to malTp and results in the $\mathrm{pH}_{0}$ modulation of basal and induced activity of MalTdependent promoters (malKp, malEp, malPp and malsp). Accordingly, the amount of $\mathrm{MalT}_{\mathrm{i}}$ produced would depend on $\mathrm{pH}_{\mathrm{o}}$ and the amount of $\mathrm{MalT}_{\mathrm{a}}$ would be higher at high $\mathrm{pH}_{\mathrm{o}}$ than at low $\mathrm{pH}_{0}$. Bukau et al. (1986) reported the osmoregulation of maltose genes during growth in MM. However, molecular mechanisms operating in osmoregulation are different from those involved in $\mathrm{pH}_{\mathrm{o}}$ regulation. Indeed, malT expression does not depend on medium osmolarity and only the basal expression of maltose genes is osmodependent. Moreover, the cAMP-CRP complex is not required for the osmoregulation of maltose genes. Ehrmann \& Boos (1987) postulated that osmoregulation is mediated by regulation of the synthesis of two endogenous inducer classes, one made under low osmolarity and the other under high osmolarity. Our results do not support the idea of $\mathrm{pH}_{\mathrm{o}}$-dependent synthesis of an endogenous inducer. Indeed, $\mathrm{pH}_{\mathrm{o}}$ regulation works when an exogenous inducer is provided and is not effective as soon as MalT synthesis does not fluctuate with the $\mathrm{pH}_{\mathrm{o}}$ because of malTp1 malTp10 mutations. On the basis of 

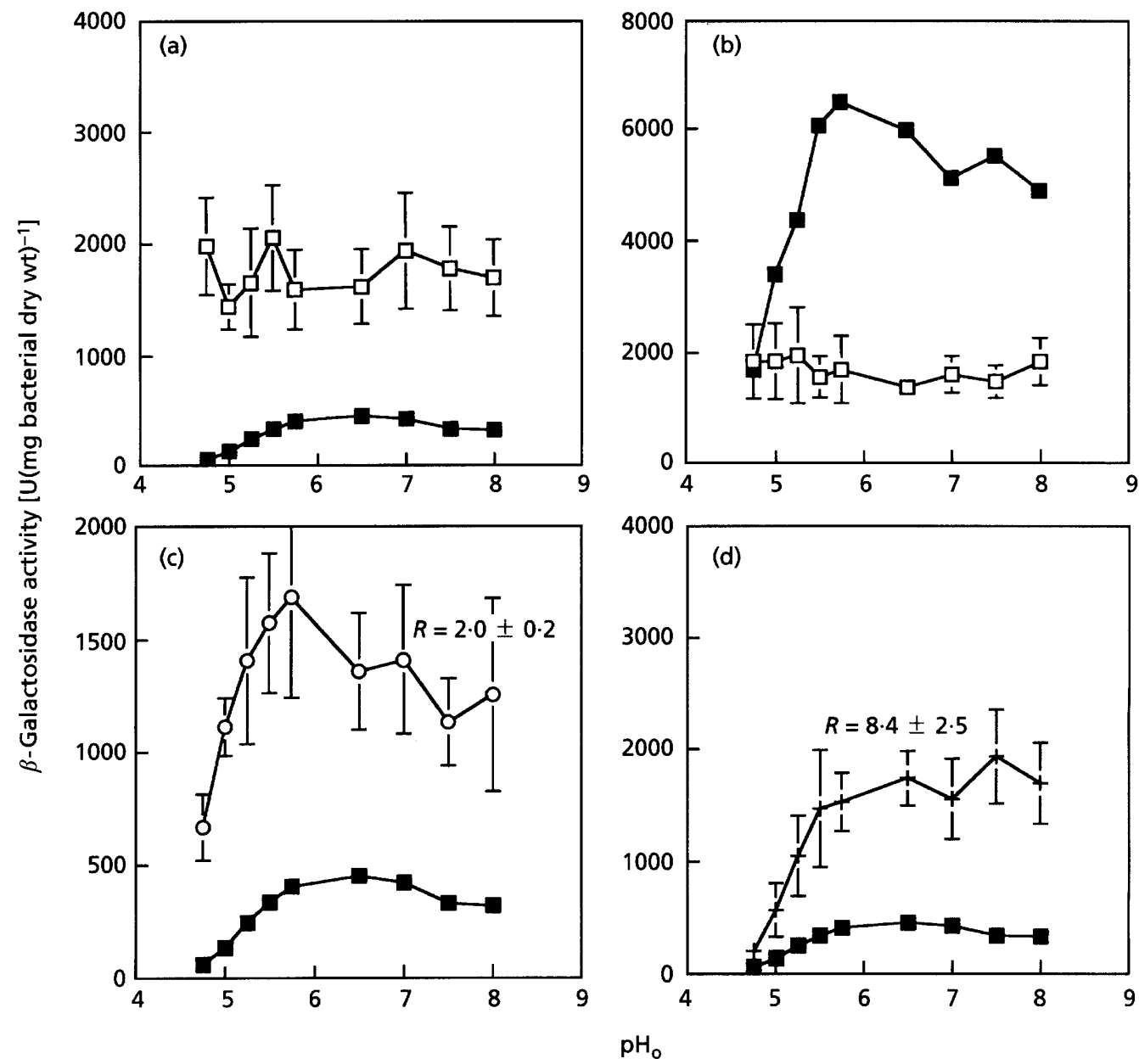

Fig. 5. Influence of malT 1 , malQ::Tn 10 and malK::Kan ${ }^{R}$ mutations on malK $\mathrm{pH}_{\mathrm{o}}$ regulation. $\beta$-Galactosidase activity was assayed during growth at $30^{\circ} \mathrm{C}$ in $\mathrm{MM}$ adjusted to different $\mathrm{pH}$ values and supplemented with ampicillin and glycerol (a, $c$ and d) or glycerol plus maltose (b). Data are mean values ( $\pm S D)$ from at least two independent experiments. Data for the wild-type strain are those presented in Fig. 1(a) and (b). $R$ factors were calculated as indicated in the legend to Fig. 1. $(a, b)\left(\right.$ malK'-lac $\left.Z^{+}\right) 1$ operon fusion on pJEL250 in a mal $T_{1} 1(\mathrm{GPH} 8561, \square)$ or wild-type $(\mathrm{GPH} 1768, \square)$ genetic background. (c) (malK'-lacZ')1 operon fusion on pJEL250 in a malQ::Tn10 (GPH8888, O) or wild-type (GPH1768, D) genetic


genetic background.

our results, we propose that in the wild-type strain during growth in $\mathrm{MM}$, the $\mathrm{pH}$ of the external medium influences malT transcription through the action of the cAMP-CRP complex. Indeed our observations regarding the deleted malTp promoter demonstrate that the minimal malT promoter contains all the regulatory regions for establishing the $\mathrm{pH}_{\mathrm{o}}$ regulation. Moreover, Mlc binding to its operator binding site was not required by the regulatory circuit leading to $\mathrm{pH}_{\mathrm{o}}$ regulation of maltose regulon.

It should be emphazised that most of the $\mathrm{pH}_{\mathrm{o}}$-regulated genes presently described are cAMP-CRP dependent (Olson, 1993). $\mathrm{pH}_{\mathrm{o}}$ modulation of the amount of cAMPCRP is unlikely. Indeed, cya and crp expression and total cAMP do not depend on $\mathrm{pH}_{\mathrm{o}}$ (Coll et al., 1994 and data not shown). Moreover, all cAMP-CRP-dependent genes are not $\mathrm{pH}_{0}$-dependent. We propose that $\mathrm{pH}_{\mathrm{o}}$ may indirectly affect cAMP-CRP binding at malTp, either by $\mathrm{pH}_{\mathrm{o}}$-induced alterations of malTp topology or by the presence of a $\mathrm{pH}_{\mathrm{o}}$-dependent effector that may act in concert with cAMP-CRP. As malTp activity depends less on $\mathrm{pH}_{\mathrm{o}}$ in the $\Delta c y a c r p^{*}$ derivative (Fig. $3 \mathrm{~b}$ ), the $\mathrm{CRP}^{*}$ protein may be locked in a configuration that is less sensitive to DNA topology alterations or to interactions with the putative coregulator. Under inducing conditions, an $R$ value of 3 for malTp leads to an $R$ value of 26 for malsp activity. This result could reveal some different features in MalT binding at malsp or some function of the periplasmic $\alpha$-amylase (MalS) in $\mathrm{pH}_{o}$ regulation. Indeed, the mal $S$ gene is inactivated by the fusion we used in this study. 
Further characterization of malTp activation by cAMPCRP aimed at the understanding of the $\mathrm{pH}_{\mathrm{o}}$ regulation of maltose genes should help to define the mechanisms able to sense and transduce the $\mathrm{pH}_{0}$ stimulus.

\section{ACKNOWLEDGEMENTS}

We are obliged to Evelyne Richet and Winfried Boos for providing strains, stimulating discussions and critical reading of the manuscript. We thank M. Berlyn, T. Elliott and P. Valentin-Hansen for providing strains and plasmids. We thank A. Garel for primer synthesis and B. Dequatre for excellent technical assistance. S. A. was supported by a grant from the Ministère de l'Enseignement Supérieur et de la Recherche. This work was supported by research grants from the Centre National de la Recherche Scientifique (UMR 5534) and the University Claude Bernard Lyon I.

\section{REFERENCES}

Bachmann, B. J. (1990). Linkage map of Escherichia coli K-12, edition 8. Microbiol Rev 54, 130-197.

Boos, W., Peist, R., Decker, K. \& Zdych, E. (1996). The maltose system of Escherichia coli. In Regulation of Gene Expression in Escherichia coli, pp. 201-229. E. C. C. Lin \& A. S. Lynch. Austin, TX: R. G. Landes.

Bukau, B., Ehrmann, M. \& Boos, W. (1986). Osmoregulation of the maltose regulon in Escherichia coli. J Bacteriol 166, 884-891.

Chapon, C. (1982). Role of the catabolite activator protein in the maltose regulon of Escherichia coli. J Bacteriol 150, 722-729.

Chapon, C. \& Kolb, A. (1983). Action of CAP on the malT promoter in vitro. J Bacteriol 156, 1135-1143.

Coll, J. L., Heyde, M. \& Portalier, R. (1994). Expression of the $n m p C$ gene of Escherichia coli $\mathrm{K}-12$ is modulated by external $\mathrm{pH}$. Identification of cis-acting regulatory sequences involved in this regulation. Mol Microbiol 12, 83-93.

Dardonville, B. \& Raibaud, O. (1990). Characterization of malT mutants that constitutively activate the maltose regulon of Escherichia coli. J Bacteriol 172, 1846-1852.

Decker, K., Peist, R., Reidl, J., Kossmann, M., Brand, B. \& Boos, W. (1993). Maltose and maltotriose can be formed endogenously in Escherichia coli from glucose and glucose-1-phosphate independently of enzymes of the maltose system. J Bacteriol 175, 5655-5665.

Decker, K., Plumbridge, J. \& Boos, W. (1998). Negative transcriptional regulation of a positive regulator; the expression of malT, encoding the transcriptional activator of the maltose regulon of Escherichia coli, is negatively controlled by Mlc. Mol Microbiol 27, 381-390.

Ehrmann, M. \& Boos, W. (1987). Identification of endogenous inducers of the mal regulon in Escherichia coli. J Bacteriol 169, 3539-3545.

Elliott, T. (1992). A method for constructing single-copy lac fusions in Salmonella typhimurium and its application to the bemA-prfA operon. J Bacteriol 174, 245-253.
Freundlieb, S. \& Boos, W. (1986). $\alpha$-Amylase of Escherichia coli, mapping and cloning of the structural gene, mals, and identification of its product as a periplasmic protein. J Biol Chem 261 , 2946-2953.

Harman, J. G., McKenny, K. \& Petrekofsky, A. (1986). Structure function analysis of three cAMP-independent forms of the cAMP receptor protein. J Biol Chem 261, 16332-16339.

Heyde, M. \& Portalier, R. (1987). Regulation of major outer membrane porin proteins of Escherichia coli $\mathrm{K}-12$ by $\mathrm{pH}$. Mol Gen Genet 208, 511-517.

Heyde, M., Coll, J. L. \& Portalier, R. (1991). Identification of Escherichia coligenes whose expression increases as a function of external pH. Mol Gen Genet 229, 197-205.

Maniatis, T., Fritsch, E. F. \& Sambrook, J. (1982). Molecular Cloning: a Laboratory Manual. Cold Spring Harbor, NY: Cold Spring Harbor Laboratory.

Miller, J. H. (1992). A Short Course in Bacterial Genetics. A Laboratory Manual and Handbook for Escherichia coli and Related Bacteria. Cold Spring Harbor, NY : Cold Spring Harbor Laboratory.

Olson, E. R. (1993). Influence of $\mathrm{pH}$ on bacterial gene expression. Mol Microbiol 8, 5-14.

Raibaud, O. \& Richet, E. (1987). Maltotriose is the inducer of the maltose regulon of Escherichia coli. J Bacteriol 169, 3059-3061.

Raibaud, O., Gutierrez, C. \& Schwartz, M. (1985). Essential and nonessential sequences in malPp, a positively controlled promoter in Escherichia coli. J Bacteriol 161, 1201-1208.

Raibaud, O., Vidal-Ingigliardi, D. \& Richet, E. (1989). A complex nucleoprotein structure involved in activation of transcription of two divergent Escherichia coli promoters. J Mol Biol 205, 471-485.

Raibaud, O., Vidal-Ingigliardi, D. \& Kolb, A. (1991). Genetic studies on the promoter of malT, the gene that encodes the activator of the Escherichia coli maltose regulon. Res Microbiol 142, 937-942.

Richet, E. \& Raibaud, O. (1989). MalT, the regulatory protein of the Escherichia coli maltose system, is an ATP-dependent transcriptional activator. EMBO J 8, 981-987.

Schwartz, M. (1987). The maltose regulon. In Escherichia coli and Salmonella typhimurium: Cellular and Molecular Biology, pp. 1482-1502. Edited by F. C. Neidhardt, J. L. Ingraham, K. Brooks Low, B. Magasanik, M. Schaechter \& H. E. Umbarger. Washington, DC: American Society for Microbiology.

Valentin-Hansen, P., Albrechtsen, B. \& Løve Larsen, J. E. (1986). DNA-protein recognition: demonstration of three genetically separated operator elements that are required for repression of the Escherichia coli deoCABD promoters by the DeoR repressor. EMBO J 5, 2015-2021.

Zilberstein, D., Agmon, V., Schuldiner, S. \& Padan, E. (1984). Escherichia coli intracellular $\mathrm{pH}$, membrane potential and cell growth. J Bacteriol 158, 246-252.

Received 16 February 1998; revised 22 July 1998; accepted 17 August 1998. 